\title{
Information and Communications Technology and Inventory Management amongst Breweries in Nigeria
}

\author{
Grace O. Akinola ${ }^{1)}$, Olusegun Timothy Odesola ${ }^{2)^{*}}$ \\ 1)2) Obafemi Awolowo University \\ Ile-Ife, Osun State, Nigeria. \\ 1) gakinola2002@yahoo.com \\ ${ }^{2)}$ segunodesola@gmail.com, segunodesola@oauife.edu.ng
}

\begin{tabular}{l} 
Article history: \\
Received 16 March 2018 \\
Revised 16 April 2018 \\
Accepted 17 April 2018 \\
Available online 28 April 2018 \\
\hline Keywords: \\
Brewery \\
Inventory \\
Inventory Management \\
Information and Communications \\
Technology \\
Inventory Management System
\end{tabular}

\begin{abstract}
This study examined the effect of ICT on inventory management amongst breweries in Nigeria. Secondary data were sourced for this study. The population for the study comprises all brewery companies quoted on the Nigerian Stock Exchange. Purposive sampling technique was used in selecting the three leading brewery companies in Nigeria, namely the Nigerian Breweries Plc; Guinness Nigeria Plc; and International Breweries Plc that represent $75 \%$ of the breweries quoted in the Nigerian Stock Exchange factsbook. Secondary data on ICT/ software costs, inventories, sales turnover/revenue, and assets were sourced from years 2006 to 2015 Annual Reports and Statements of Accounts of the three selected breweries and the Nigeria Stock Exchange facts book. The data collected were analyzed using descriptive statistics ( tables, mean and standard deviation) and inferential statistics (Ordinary Least Square (OLS) method). The results also showed that ICT usage had no significant positive relationship on inventory management $(\mathrm{t}=0.021, \mathrm{P}>0.01)$. The study concluded that ICT had no significant positive effect on inventory management in the Nigerian Brewery industry. It is recommended that brewery firms in Nigeria should deploy the right software for inventory management. The limitation of this research is what were used to measure the inventory management and Information and Communications Technology (ICT) as contrary results could be obtained if these variables are measured using other yardsticks. The improvement of the respondent required to see the other problem and another kind of business.
\end{abstract}

\section{INTRODUCTION}

Inventory can be termed as inactive but a utilizable stock of materials that do not bring in any income to the organization when static. Studies have shown that virtually all organizations whether it is industrial, educational, sole ownership, health, and government institutions among others have cause to preserve one type of inventory or the other in the course of carrying out the firm's operations. In a real-life situation, demand and supply of a specific product or raw materials are not constantly the same and so there is the need to keep inventory in an organization all the time in order to reduce the costs connected with the inventory control. It is obvious that experts managing a business need goods that can be kept for one future use or the other in the organization. It will not be out of place to conclude that in an organization there are various types of items that are usually stored as inventory [1].

Inventory management can be illustrated as procedures designed by an organization to manage its raw materials, semi-finished materials (work-in-progress), finished good, consumables and spare parts so that the organization can lessen costs associated with inventory, ensure unhindered production processes and thereby achieve its stated goals and objectives. Good and amendable inventory management is key to the successful operations of any industrialized

\footnotetext{
${ }^{*}$ Corresponding author
} 
setup. Inventory management is to any flourishing manufacturing setting as blood to the human body. Inventories are assets of an organization that are being kept for future use by the organization. Musa [2] contends that information and communications technology (ICT) is a general term that comprises of all sophisticated technologies being deployed in manipulating and communicating information.

Deployment of ICT has not only made reporting of events to be done at a fast speed as if the whole world is a small village through the use of internet but has also aided virtually all sectors of human endeavors. Kanaracus [3] said despite the fact that there was an economic meltdown in 2008 which affected many businesses adversely all over the world, organizations kept on increasing their expenditures on information and communications technology (ICT) systems which invariably increases their budgets. Justifying the unusual investments, Petter, Delone, and McLean [4] posited that firms only concentrate on unfolding, applying and assessing utilitarian ICT systems in their operations so as to achieve set goals and objectives. The utilitarian ICT systems include e-commerce, decision support systems, e-banking and knowledge management systems among others.

Obasan [5] posits that the deployment of ICT in business organizations has considerately improved operations and performances of businesses in Nigeria. Management of inventories has become a matter of concern in the management of business organizations in the world over. This is first and foremost because inventories form the most significant percentage of the current assets and subsequently its management has become a critical success factor for organizations that want to develop [6]. The modern method of inventory management stock tracing was characterized by the continuous alert of the bar code being scanned at a point of sale lane. In the earliest days of shop keeping, wholesalers wrote down purchases or they looked at how many units were procured at the end of the day's business and then use this to project into the future needs of their businesses [7].

Olawale [8] in a Breweries Sector Report 2014 posits that Africa has an end user market of over one billion people of beer consumption, average Gross Domestic Product growth of 5\% up to 2020 and a beer consumption per capita of 9 liters (vs.25liter peer average), the growth of beer market in the continent of Africa is without doubt credible. Also, Olawale [8] said that all eyes are on Nigeria as far as beer consumption is concerned being a heavily populated nation and largest (still growing) economy in Africa, with considerable latent for a double-digit growth. The Nigerian brewery industry is not completely left to mainly Nigerian investors as leading international players like Heineken N.V is in charge of $70 \%$ of Nigerian beer market with majority stake in Nigerian Breweries Plc and Champion Breweries Plc while Diageo controls 27\% through its ownership of Guinness Nigeria Plc and SABMiller controls 3\% of its stake in International Breweries Plc and Pabod Breweries Ltd. The massive consumer market, beer consumption deficit and demand deficit plus powerful rivalry are amongst the major encouraging factors in the Nigerian brewing space. It is therefore pertinent to undertake this study because of the position of the Nigeria market and the effect which the proper management of inventory vis-à-vis the use of information and communications technology will have on the performance, profitability, and effectiveness of firms in the Nigerian Brewery industry.

Some authors have over the years described inventory as commonly the biggest assets behind fixed assets. To be specific, Itod et.al [6] said inventory forms the most significant percentage of current assets of organizations. Therefore, all hands must be on deck to reduce these costs to the nearest minimal in order to strengthen the competitive edge of the organization. The use of ICT powered inventory management system will help an organization to strike a balance between customer's demand and costs of holding inventory in such organization.

Studies have shown that in manufacturing organizations like the Brewery industry, that inventory management has not been given proper attention despite its role in determining the performance of such organizations in terms of effectiveness, efficiency, productivity, and profitability. The industry has many stocks to contend with i.e. raw materials of different types, work-in-progress of varying degrees as well as finished products of different brands. So to monitor the levels of these varying categories of stock items physically has been discovered to be a herculean task as this will be prone to human errors.

There is scarcity of study on the effect of ICT in business enterprises especially on the management of inventory in the brewery industry in Nigeria while the few existing studies on ICT in Nigeria were paying attention to the banking sector of the Nigeria economy [5] [9-11] and the small-medium scale industries [12], effects of ICT on inventory management was left out.From the above submissions, it is clear that studies on how information and communications technology (ICT) enhances inventory management in the Nigerian brewery industry have not been adequately conducted, hence the need for this study.

The research hypothesis formulated for the study is:

$\mathbf{H}_{\mathbf{0}}$ : Information and communications technology has no significant effect on inventory management in the Nigerian brewery industry

$\mathbf{H}_{\mathbf{1}}$ : Information and communications technology has significant effect on inventory management in the Nigerian brewery industry. 


\section{LITERATURE REVIEW}

\section{A. Inventory}

At any time an organization has resources that it does not use instantly, it places those materials into stock. Stock consists of all the useful and relatively scarce tangible item and materials that are stored by a firm. In a nutshell, a plant saves a stock of raw materials for its products. Some examples that readily comes to mind are: television broadcasting stations have stocks of recorded programmers; a farmer stocks hay to feed his animals over a period of time when hay will not be available; a research company has a stock of its research findings kept in place for ease retrieval; a bank holds cash for its day-to-day transactions in a bid to meet its customers' demand. From the foregoing, inventory is a store of items that are kept for future use. An inventory can, therefore, be described as a list of the items held in stock by a company [13].

\section{B. The Review of Empirical Literature}

The empirical review of some studies that are directly or indirectly related to this article was carried out. Some of these studies were examined in order to identify the gap which this current study is about to fill. From a study conducted by Datta and Agarwal [14] titled Telecommunications and economic growth, it was discovered and concluded from the findings that investments in ICT by business organizations can as well reduce operational costs (some of these costs fall within inventory management and which sound inventory management intends to minimize) and facilitate better communication. The results of the study confirm a significant and positive relationship between ICT infrastructure and growth. It was discovered that ICT investment is increasingly identified as one with a strong potential to improve economic productivity and growth. The study used a dynamic panel data from 22 Organization for Economic Co-operation and Development countries. This study used secondary data from Nigeria which is one of the developing countries to assess the effect of ICT on inventory management in the brewery industry.

Rabah and Mahmassani [15] did a study on the impact of information and communications technology on Logistics and Freight Transportation; Example of Vendor-Managed Inventories and put up a structure to evaluate the effects of ICT on supply-chain management and logistics operations, as well as freight movement. The authors illustrated and quantified cost savings that can be obtained from sharing of information between supply-chain partakers, the example of a vendor-managed-inventory (VMI) strategy in a two-level distribution channel was examined. The study concluded that drops in overall cost are attained across all cases examined. The study was conducted in a developed economy using the Logistics and Freight Transportation sector. This study assessed the situation in breweries to see if similar results will be obtained with respect to the effect of ICT on inventory management of brewery industry. It was also discovered that majority of the investigations were done using descriptive statistics as against the use of inferential statistics.

Momanyi and Sanewu [16] resolved that ICT has had a superior influence on the control of inventory in view of effectiveness, easiness of retrieving information and correctness by this means influencing organizational output. It also indicated that there were challenges during the technological integration of ICT into work operations because workers without sufficient knowledge in using the new arrangement have led to extra cost in training the respective workers while employee opinion of the new ICT system led to internal opposition to change thus reducing the pace of execution. The results are in tandem with what happens when a new technology is introduced to a place of work as the study was carried out in Kenya Transport Organization that has just started to incorporate the use of Information and communications technology in its operations. However, the study may not give a true picture of the impact of ICT on Kenya Ferry Services. This is simply because using the descriptive analysis to analyze the data for the research may give results that are totally different if inferential statistics are used. This study is of opinion that the results from that study may not be a true reflection of the effect of ICT on inventory management of companies in the Nigerian brewery industry because of the types and nature of the stock items being managed in the industry. Also, inferential statistics were used for the analysis of data while the ICT cost was used to investigate the effect of ICT on inventory management in the Nigerian brewery industry.

\section{Conceptual Model}

Schematic Diagram of The Relationship between Information and Communications Technology and Inventory Management can be seen in figure 1. 


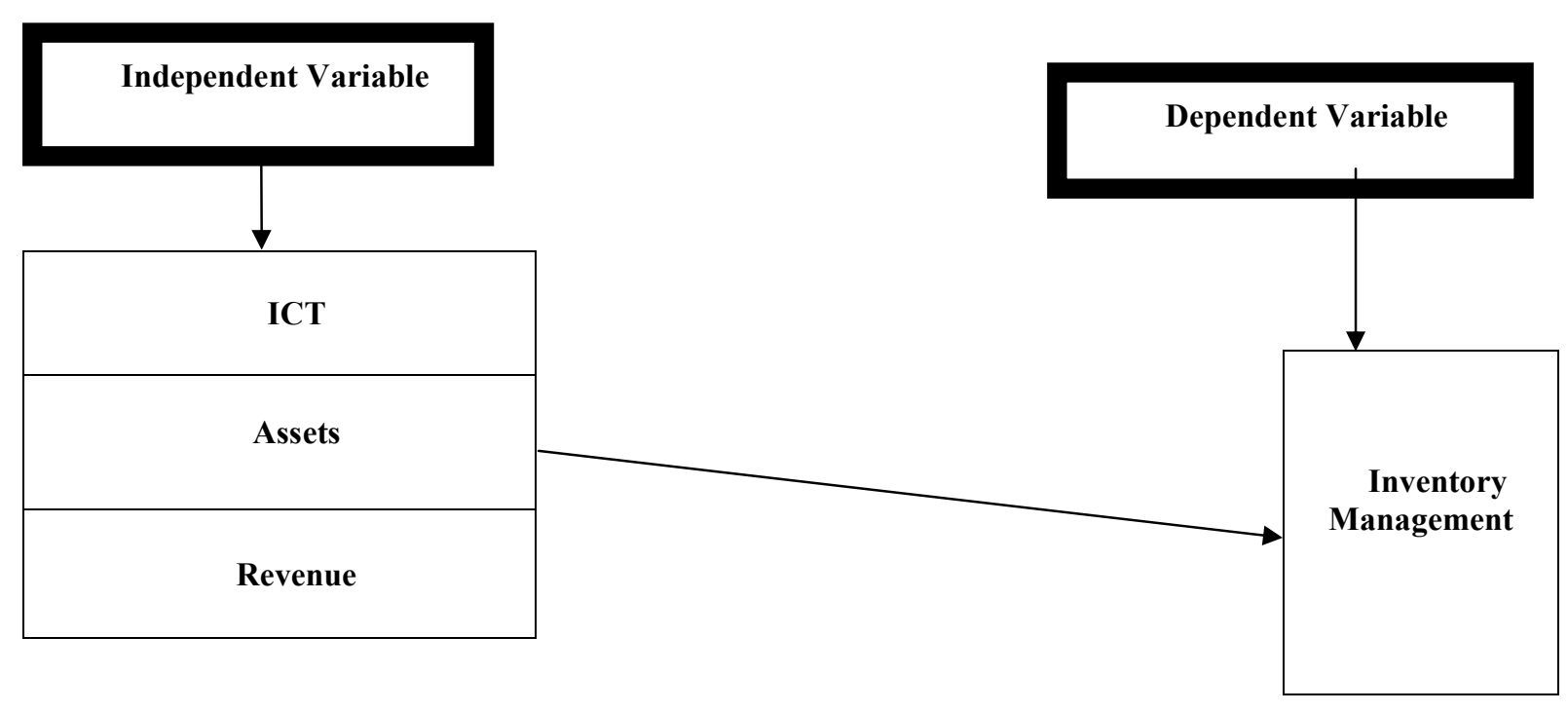

Figure. 1 Schematic Diagram Showing The Relationship between Information and Communications Technology and Inventory Management.

\section{MethodS}

Secondary data were utilized for this study. Secondary data on ICT/ software costs, inventories, sales turnover/revenue, and assets were sourced from years 2006 to 2015 Annual Reports and Statements of Accounts of the three selected breweries and the Nigeria Stock Exchange facts book. The data collected were analyzed using percentages and t-test statistics. The population for the study comprises all members of staff of brewery companies quoted on the Nigerian Stock Exchange. Purposive sampling technique was used in selecting the three leading brewery companies in Nigeria. They represent $75 \%$ of the breweries quoted in the Nigerian Stock Exchange facts book namely the Nigerian Breweries Plc; Guinness Nigeria Plc; and International Breweries Plc.

For the purpose of this study, a regression model was adopted. There are two identified variables which are; dependent and independent variable. Let inventory management be represented by INV, information communications technology be represented by ICT, revenue is represented by REV and assets be represented by ASS.

The equation for the relationship between these variables can be specified in implicit form as follow:

$$
\mathrm{INV}=\mathrm{f}(\mathrm{ICT}) \text {. }
$$

Equation (1) can be expressed in explicit panel form as:

$$
\mathrm{INV}=\beta_{0}+\beta_{1} I C T_{i t}+\beta_{2} R E V_{i t}+\beta_{3} A S S_{i t}+\varepsilon_{t}
$$

Where $\beta \_0$ is the constant term of the model, $\beta \_1, \beta \_2$, and $\beta \_3$ are the coefficients of the dependent variables (that is, inventory management, revenue, and assets respectively) and $\varepsilon_{-} t$ is the stochastic error term.

Express Equation (2) in log form in order to scale and reduce the large value of the variables which are in millions naira. Thus, we have:

$$
\begin{gathered}
\operatorname{logINV}=\beta_{0}+\beta_{1} \log I C T_{i t}+\beta_{2} \log R E V_{i t}+\beta_{3} \log A S S_{i t}+\varepsilon_{t} \\
\text { IV. RESULTS }
\end{gathered}
$$

The descriptive statistics were carried out before analyzing time-series and statistical properties of the data. We $\log$ values of the descriptive statistics of the variables used in the study. The results are presented in Table 1. This is done in order to correct the problems of multicollinearity among the variables which can bias the result of the regression estimate. The numerical descriptive statistics below showed the shape of the distribution measured by skewness which is the deviation from symmetry; Kurtosis - to measure whether the data are peaked or flat. Also, Jacque-Bera is being used to measure normalcy of the data distribution. The measure of central of tendency was the median and mean which gave an estimate of the center of the distribution. The measure of variability was the 
minimum and maximum values, the standard deviation from the mean and the sum squared deviation. After examining the variables, we discovered that the variables tend towards symmetry (skewness). The total number of observation used was 23 , the kurtosis and skewness of the log values of the variables are between -0.38 and 3.45 values and thus tend towards a normal distribution. The values of $\mathrm{J}$ argue-Bera showed normal distribution of our data and statistically significant level. Both the mean and median were almost the same when the log values of our data were considered. Furthermore, standard deviation result shows that assets, that is, (LOGASS) are the least dispersed variable (0.926) while the revenue (LOGREV) is the widely dispersed variable (3.099); when the standard deviation of the variables was considered. The descriptive tables are presented below:

TABLE I

DESCRIPTIVE PROPERTIES OF THE DATA (LOG FORM) SOURCE; AUTHOR'S COMPUTATION, 2016

\begin{tabular}{lcccc}
\hline \hline & LOGINV & LOGICT & LOGREV & LOGASS \\
\hline Mean & 16.26532 & 12.95157 & 15.80171 & 17.99196 \\
Median & 16.59785 & 13.84631 & 16.84319 & 17.92859 \\
Maximum & 17.16466 & 14.58296 & 19.49877 & 19.69106 \\
Minimum & 14.30805 & 9.366318 & 9.371438 & 16.47495 \\
Std. Dev. & 0.933265 & 1.664767 & 3.098759 & 0.926369 \\
Skewness & -1.186584 & -0.846485 & -0.559960 & 0.318696 \\
Kurtosis & 2.852802 & 2.280852 & 1.809385 & 2.390324 \\
Jarque-Bera & 5.418025 & 3.242352 & 2.560459 & 0.745558 \\
Probability & 0.066603 & 0.197666 & 0.277973 & 0.688817 \\
Sum & 374.1023 & 297.8860 & 363.4392 & 413.8150 \\
Sum Sq. Dev. & 19.16165 & 60.97185 & 211.2507 & 18.87950 \\
Observations & 23 & 23 & 23 & 23 \\
\hline
\end{tabular}

Effect of information communications and technology (ICT) on inventory (INV) and the interaction with other variables, that is, revenue (Rev) and assets (ASS) was carried out using Ordinary Least Square (OLS) method. The result is presented in Table 2 and Table 3, respectively.

TABLE 2

RESULTS OF ORDINARY LEAST SQUARE REGRESSION SOURCE; AUTHOR'S COMPUTATION; 2016

\begin{tabular}{lcccc}
\hline \hline Variables & $\boldsymbol{\beta}$ & std-error & t-stat & p-value \\
\hline Constant & 6.660709 & 2.610667 & 2.551344 & 0.0195 \\
ICT & 0.275526 & 0.094645 & 2.911158 & $0.0090^{* * *}$ \\
Revenue & -0.053573 & 0.039748 & -1.347827 & $0.1936^{* *}$ \\
Assets & 0.382541 & 0.170282 & 2.246513 & $0.0368^{*}$ \\
\hline R-squared & & 0.670919 & Mean dependent var & 16.26532 \\
Adjusted R-squared & & 0.618959 & S.D. dependent var & 0.933265 \\
S. E. of Regression & & 0.576091 & Akaike info criterion & 1.891668 \\
Sum squared resid & & 6.305734 & Schwarz criterion & 2.089146 \\
Log likelihood & -17.75419 & Hannan-Quinn criterion & 1.941333 \\
F-statistics & 12.91219 & Durbin-Watson stat & 0.732084 \\
\hline Probability (F-statistics) & & \multicolumn{3}{l}{0.000079} \\
\hline$* * *, * *, *$ significant at $1 \%, 5 \%, 10 \%$ & & & \\
\hline
\end{tabular}

TABLE 3

AUTOCORRELATION RESULTS OF ORDINARY LEAST SQUARE REGRESSION SOURCE; AUTHOR'S COMPUTATION; 2016

\begin{tabular}{lcccc}
\hline \hline Variables & $\boldsymbol{\beta}$ & std-error & t-stat & p-value \\
\hline Constant & 16.87264 & 3.017762 & 5.591109 & 0.0001 \\
Log ICT & 0.001860 & 0.086510 & 0.021502 & $0.9831^{* * *}$ \\
Log Revenue & 0.006373 & 0.025673 & 0.248254 & $0.8073^{* *}$ \\
Log Assets & -0.000156 & 0.088843 & -0.001761 & $0.9986^{*}$ \\
AR(1) & 0.933229 & 0.058174 & 16.04197 & 0.0000 \\
\hline R-squared & & 0.947455 & Mean dependent var & 16.34131 \\
Adjusted R-squared & 0.933443 & S.D. dependent var & 0.891293 \\
S. E. of Regression & 0.229942 & Sum squared resid & 0.793099 \\
Durbin-Watson stat & & 2.752368 & F-statistics & 67.61718 \\
Instrument rank & 5 & Probability (F-statistics) & 0.000000 \\
\hline Inverted AR Roots & 5 & 93 \\
\hline$* * *, * *, *$ significant at $1 \%, 5 \%, 10 \%$ & \\
\hline
\end{tabular}




\section{DISCUSSION}

From the equation (3), the specification of the model can be written as:

$$
\operatorname{logINV}=16.87264+0.001860 I_{C T} T_{i t}-0.006373 R E V_{i t}-0.000156 A S S_{i t}+0.933229 \mathrm{AR}_{1}+\varepsilon_{t}
$$

The coefficient of ICT has an insignificant positive relationship on Inventory with the probability value of less than $5 \%$ (Prob. $=0.9831>0.05$ ). This revealed that 1 percentage point increase in ICT will bring about 0.001860 percentage point increase in Inventory. Also, the coefficient of revenue (REV) has an insignificant positive relationship on Inventory with the probability value of 0.8073 (i.e. Prob. $=0.8073>0.05$ ). This revealed that 1 percentage point increase in revenue will bring about 0.006373 percentage point increase in Inventory. Furthermore, the coefficient of assets (ASS) has an insignificant positive relationship on Inventory with the probability value of 0.9986 (Prob. $0.9986>0.05$ ). This revealed that 1 percentage point increase in assets will bring about 0.000156 percentage point decreases in Inventory.

The coefficient of the constant term of 16.87264 explains that when all Information and Communication Technology (ICT), Revenue (REV) and Assets (ASS) are held constant, there is 16.87264 percentage point decrease in Inventory. Also, the R2 of $95 \%$ determines the overall joint significant of the variables. This reveals that $95 \%$ of the changes in the dependent variable (that is, Inventory) are being explained by the independent variables, That is, Information and Communication Technology (ICT), Revenue (REV) and Assets (ASS).

With the probability value of greater than $5 \%($ Prob. $=0.9831<0.05)$. This revealed that 1 percentage point increase in ICT will bring about 0.001860 percentage point increase in inventory. Therefore the null hypothesis is accepted which states that information and communication technology does not have a significant effect on inventory management amongst breweries in Nigeria.

From the empirical analysis conducted and the test of hypothesis carried out, the study found that there was no significant relationship between ICT and inventory management, as ICT was found not to have a positive effect on inventory management among Breweries (International Breweries Plc, Nigeria Breweries Plc, and Guinness Nigeria Plc) in Nigeria. Reasons for this finding may include the variables used to measure the ICT and inventory management, the volume of data used for the analysis, erratic power supply, the cost of ICT tools and software in Nigeria. This finding is at variance with the findings from Zengwa and Choga [17] Fridah [18], Momanyi and Sanewu [16], Owuor and Mwangi [19], Muathe, Nelson and Gorretty [20], Datta and Agarwal [14], Rabah and Mahmassani [15], and Yansong [21]. In all these studies, ICT was discovered to have a significant effect on inventory management resulting into efficiency, effectiveness and improved customer's satisfaction.

This finding is at par with several studies conducted in the 1980s in which there was no connection between IT investment and productivity in the United States economy. From one of the studies, Roach [22] established that even though ICT investment for every salaried employee in the service division enlarged by some hundred percent beginning 1977 to 1989, productivity for every employee did not rise noticeably. This circumstance was denoted as the "productivity paradox" [23][24].

\section{CONCLUSIONS}

Based on the findings of this study, the study concluded that information and communications technology had no significant effect $(t=0.021, P>0.01)$ on the inventory management in the Nigerian Brewery industry. It is recommended that firms in the Nigerian brewery industry have a duty to devote more in contemporary technologies, for example, information communications technology so as to accomplish integration, lessen communication charges, enhance effectiveness and increase information sharing which will ultimately pave way for an improved performance.

\section{REFERENCES}

[1] O A Adedayo, Olu Ojo, and J K Obamiro, Operations Research in Decision Analysis and Production Management, Lagos Pumark Nigeria Limited, Ed., 2010.

[2] A.A Musa, "Foundation of Information and Communication Technology Course Manual," Lagos : National Open University of Nigeria, 2013.

[3] C. Kanaracus, "Gartner : Global IT Spending Growth Stable.," Info World, 2008.

[4] S., Delone, W., \& McLean, E. Petter, "Measuring Information System Success : Models, Dimension, Measures and Interrelationship," European Journal of Information System, vol. 17, pp. 236-263, 2008.

[5] K.A Obasan, "Information and Communication Technology and Banks Profitability in Nigeria," Australian Journal of Business and Management Research, vol. 1, no. 4, pp. 102-107, 2011. 
[6] J., Maji, S.R \& Abdu, M Itodo, "Inventory Management as a Veritable Tool for Simulating Business Growth in Nigeria," Journal of Management Sciences, vol. 4, no. 1, pp. 64-77, 2010.

[7] R Miller, Inventors Control: Theory and Practice. New Jersey: Prentice Hall, 2010.

[8] Olawale O., "Breweries Sector Report. Lagos Meristem Securities Limited," 2014.

[9] E Osabuohien, "ICT and Nigerian Banks Reforms: Analysis of Anticipated Impacts in Selected Banks," Global Journal of Business Research, vol. 2, no. 2, pp. 67-76, 2008.

[10] Y. A. and Akingbade, W.A Dauda, "Technology Innovation and Nigeria Banks Performance : The Assessment of Employees and Customer's Responses," American Journal of Social and Mnagement Sciences, vol. 2, no. 3, pp. 329-340, 2011.

[11] O.S Emmanuel, "ICTS's Service Delivery and Operational Performance in Nigerian Banks : A Survey of Empirical Research," African Research Review, vol. 5, no. 4, pp. 44-59, 2011.

[12] J.O, and Akanbi, T.A Adewoye, "Role of Information and Communication Technology Investment on The Profitability of Small Medium Scale Industries-A Case of Sachet Water Companies in Oyo State," Journal of Emerging Trends in Economics and Management Sciences, vol. 3, no. 1, pp. 64-71, 2012.

[13] Donald W., Inventory Control and Management, 2nd ed.: West Sussex: John Wiley \& Sons Ltd, 2013.

[14] A. and Agarwal, S. Datta, "Telecommunications and Economic Growth : A Panel Data Approach," Applied Economics, vol. 36, no. 15, pp. 1649-1654, 2004.

[15] M Y Rabah and H S Mahmassani, Impact of Electronic Commerce on Logistics Operations: A Focus on Vendor Managed Inventory (VMI) Strategies.: Unknown Publisher, 2002.

[16] Momanyi E. M. \& Sanewu E.N., "The Impact of Information Communication Technology on Inventory Control System in Transport Organization," European Journal of Logistics Purchasing and Supply Chain Management, vol. 2, no. 1, pp. 17-41, 2014.

[17] O Zengwa and F Choga, "The Role of Information \& Communication Technology (ICT) In Company Inventory Management in Zimbabwe: 2011-2013," IOSR Journal of Business and Management, vol. 18, no. 1 ver.2, pp. 56-60, 2016.

[18] M. Fridah, "Impact of Information Technology on Inventory Management in Supermarkets in Nairobi City Country," Research Project School of Business, University of Nairobi, 2015.

[19] O. J and Mwangi, M. W. Owuor, "Effect of ICT on Successful Implementation of Vendor Managed Inventory among Manufacturing Firms in Nakuru Country, Kenya," International Journal of Science and Research, vol. 3, no. 5, 2014.

[20] S M Muathe, H Nelson, and A Gorrety, "An Empirical Study on the relationship between Organizational Factors and Adoption of ICT among Health Related SMES in Nairobi, Kenya," International Journal of Arts and Commerce, vol. 2, no. 3, pp. 1-16, 2013.

[21] Yansong L., The Development of an Intelligent Inventory Management System.: Scalford University of Salford, 1997.

[22] S Roach, America's Technology Dilemma: A Profile of the Information Economy. New York: Morgan Stanley, 1987.

[23] E., \& Hitt, L.M Brynjolfsson, "Computing Productivity : Firm-Level Evidence," vol. 85, no. 4, pp. $793-808$.

[24] R Solow, We'd better watch out. New York: New York Times Book Review, 1987. 